\title{
The sodium iodide symporter gene and its regulation by cytokines found in autoimmmunity
}

\author{
R A Ajjan, P F Watson, C Findlay, R A Metcalfe, M Crisp", \\ M Ludgate ${ }^{1}$ and A P Weetman \\ Department of Medicine, University of Sheffield Clinical Sciences Centre, Northern General Hospital, Sheffield S5 7AU, UK and ${ }^{1}$ Department of Pathology, \\ University of Wales College of Medicine, Heath Park, Cardiff CF4 4XN, UK \\ (Requests for offprints should be addressed to A P Weetman)
}

\begin{abstract}
Iodide concentration by the thyroid gland, an essential step for thyroid hormone synthesis, is mediated by the $\mathrm{Na}^{+} / \mathrm{I}^{-}$ symporter (NIS). To identify factors that may regulate this process, we have studied NIS gene expression in the Fisher rat thyroid cell line (FRTL-5) by a semi-quantitative reverse transcription-polymerase chain reaction (RTPCR) technique. Increasing concentrations of bovine TSH $(0 \cdot 1,1,10,50$ and $100 \mathrm{mU} / 1)$, with or without tumour necrosis factor- $\alpha$ (TNF $\alpha)$, interferon- $\gamma($ IFN $\gamma)$ or interleukin-1 $\alpha$ (IL-1 $\alpha)$ were added to FRTL-5 cells previously deprived of TSH for a minimum of 5 days. RNA was extracted and samples were studied for NIS expression. TSH enhanced NIS mRNA expression in a dose-dependent manner, with induction evident at $0.1 \mathrm{mU} / 1$, reaching a peak at $50 \mathrm{mU} / 1$, an effect detected after $6 \mathrm{~h}$ of stimulation, but not in the first $2 \mathrm{~h}$. Both TNF $\alpha$ and, to a lesser extent, IL-1 $\alpha$ inhibited basal and
\end{abstract}

TSH-induced NIS expression. High concentrations of IFN $\gamma$ also downregulated TSH-stimulated NIS mRNA expression.

Using the same technique, we also investigated NIS mRNA tissue distribution in two male and one female Wistar rats. High levels of NIS expression were detected in the thyroid, stomach, and mammary gland, lower levels were found in the intestine, adipose tissue and liver, borderline levels were expressed in the salivary gland, and no expression was detected in the kidneys.

In summary, we have shown that TSH upregulates rat NIS gene expression in vitro, and this induction can be modulated by cytokines. Analysis of the distribution of rat NIS mRNA ex vivo demonstrated variable levels of NIS transcription in different tissue samples.

Journal of Endocrinology (1998) 158, 351-358

\section{Introduction}

Iodide $\left(\mathrm{I}^{-}\right)$uptake by the thyroid gland is an essential step for the formation of thyroid hormones and is mediated by the sodium/iodide symporter (NIS). The NIS is localised to the basolateral membrane of thyroid follicular cells (TFC) transporting extrafollicular $\mathrm{I}^{-}$using the sodium $\left(\mathrm{Na}^{+}\right)$gradient generated by the $\mathrm{Na}^{+} / \mathrm{K}^{+}$ATPase as an energy source (Chambard et al. 1983). Although the physiological properties of the NIS are well characterised, its amino acid sequence was described only recently (Carrasco 1993, Dai et al. 1996, Smanik et al. 1996). Studies on NIS gene expression have been limited, and to date little is known concerning the factors that modulate NIS mRNA expression. In addition, iodide transport is not exclusive to the thyroid gland, as it is also found in other organs including the gastric mucosa, mammary and salivary glands (Halmi 1961), and the relative NIS gene expression in these tissues remains to be investigated.
Several lines of evidence suggest that cytokines have an important role in autoimmune hypothyroidism and Graves' disease. These molecules, produced by both the infiltrating inflammatory cells and the TFC in autoimmune thyroid disease (Bagnasco et al. 1987, Del Prete et al. 1989, Zheng et al. 1992, Watson et al. 1995, Ajjan et al. 1996), can induce immunological changes in TFC in addition to affecting their growth and function (Todd et al. 1985, Weetman \& Rees 1988, Tandon et al. 1992, Vargas et al. 1994, Tominaga et al. 1991, Huber \& Davies 1990, Rasmussen et al. 1994, Pang et al. 1993). Previous studies have shown that cytokines can modulate iodide uptake of TFC by mechanisms that remain unclear (Pang et al. 1993, Rasmussen et al. 1994). In the present study, we have investigated NIS tissue distribution in Wistar rats in a variety of tissues, and the level of NIS gene expression was evaluated using a semi-quantitative reverse transcriptionpolymerase chain reaction (RT-PCR) technique. We have also studied the effect of IL-1 $\alpha$, IFN $\gamma$ and TNF $\alpha$ 
on NIS mRNA expression in FRTL-5 cells, a rat thyroid cell line, using the above technique.

\section{Materials and Methods}

Tissue samples

The thyroid, mammary gland, stomach, intestine, liver, salivary gland, kidney, orbital fat, shoulder fat, epididymal fat and visceral fat were excised from two male and one female lactating Wistar rats. Kidney, mammary gland, orbital, shoulder and epididymal fat tissues were analysed from one animal. Thyroid, stomach, intestine, liver and visceral fat tissues were studied in duplicate, and salivary gland tissues were taken from three rats. Tissue samples were immediately snap frozen in liquid nitrogen and kept in liquid nitrogen until required for analysis.

\section{FRTL-5 cell culture}

FRTL-5 cells, passaged up to 20 times, were obtained from Dr L Kohn (NIH, Bethesda, MD, USA) in 1994. These cells were grown in 24-well plates as previously described (Weiss et al. 1984a,b), except that thyroid-stimulating hormone $(\mathrm{TSH})$ was used at concentrations of $1 \mathrm{U} / \mathrm{l}$. When cells reached $70 \%$ confluence, they were deprived of TSH for a period of 5-7 days. Cells were then treated with $100 \mathrm{mU} / 1$ of either bovine (b) TSH (preparation 53/11, National Institute for Biological Standards and Control, Potters Bar, Hertfordshire) or human (h) recombinant TSH (Sigma, Poole, Dorset, UK) and RNA was extracted after $0 \cdot 5,1,2,6,12$ and $24 \mathrm{~h}$ of stimulation, as described below. RNA was also extracted after the application of increasing concentrations of TSH $(0 \cdot 1,1,10,50$ and $100 \mathrm{mU} / \mathrm{l})$ for a period of $12 \mathrm{~h}$. Both TSH-stimulated and TSH-deprived FRTL-5 cells were further treated with IL-1 $\alpha(10,100$ or $1000 \mathrm{U} / \mathrm{ml}$; kindly provided by Hoffman-La Roche Inc., Nutley, NJ, USA), IFN $\gamma(10,100$ or $1000 \mathrm{U} / \mathrm{ml}$; Boehringer Mannheim Ltd, Lewes, East Sussex, UK) or TNFa $(10,100$ or $1000 \mathrm{U} / \mathrm{ml}$; Calbiochem, Nottingham, UK) and RNA was extracted after $12 \mathrm{~h}$ of stimulation. Experiments were repeated with two different cultures, and PCR were performed at least twice on each set of cell cultures. Iodide uptake experiments were also performed in cells stimulated with bTSH or hTSH with or without the addition of cytokines.

\section{RNA extraction and $\mathrm{DNN}$ synthesis}

RNA was extracted from thyroid cell culture and whole tissue (3-50 $\mathrm{mm}^{3}$ pieces) by using TRIzol (Gibco, Paisley, UK) according to the manufacturer's protocol. Moloney murine leukaemia virus reverse transcriptase (MMLV-RT) was used to synthesize cDNA as described previously (Ajjan et al. 1996).

\section{PCR amplification}

Duplex PCR was performed in $50 \mu \mathrm{l}$ amplification reaction which contained: $5 \mu \mathrm{l} 10 \times$ concentrated buffer
(10 $\mathrm{mM} \mathrm{MgCl}_{2}, 100 \mathrm{mM}$ Tris- $\mathrm{HCl} \mathrm{pH} 8 \cdot 3,0 \cdot 1 \%$ gelatin, $500 \mathrm{mM} \mathrm{KCl}, 1 \%$ Tween 20, 1\% Nonidet NP40; all from Sigma), 2.5 U Taq DNA polymerase (Promega, Southampton, UK), $0.1 \mathrm{mM}$ each dNTP, $1.5 \mu \mathrm{cDNA}$, and $40 \mu \mathrm{l}$ autoclaved, deionised water.

Amplifications were carried out using cycles of $94^{\circ} \mathrm{C}$ for $1 \mathrm{~min}, 55^{\circ} \mathrm{C}$ for $1 \mathrm{~min}$, and $72{ }^{\circ} \mathrm{C}$ for $1 \mathrm{~min}$. In addition to the NIS primers, $\beta$-actin primers were used in the same reaction, to enable semi-quantitation, and to provide a control for the integrity of the cDNA. Initial experiments were carried out to optimise the PCR conditions using a variety of primer and magnesium concentrations. We have also applied different PCR cycles, ranging from 26 to 30 and 22 to 24 cycles for NIS and $\beta$-actin respectively, to ensure the linearity of the amplification reactions. For tissue culture, 23 cycles were used to amplify $\beta$-actin, whereas $26-28$ for TSH-stimulated and 28-30 cycles for TSH-deprived cells were used to amplify NIS-specific PCR product. Additional house-keeping genes, 7B6 and glyceraldehyde phosphate dehydrogenase (GAPDH), were also tested using 23-25 cycles for the former and 26-28 cycles for the latter. For tissue samples, 23 cycles for $\beta$-actin and 27 cycles for NIS were used except for adipose tissue from the orbit, shoulder and epididymis, for which 29 and 33 cycles were used for $\beta$-actin and NIS amplification respectively. Samples negative for NIS expression using 25-28 cycles were further subjected to 35-37 cycles of PCR amplification.

The oligonucleotide primers and probe of NIS were designed according to sequences published earlier (Dai et al. 1996, Ajjan et al. 1996). The sequences were as follows: NIS primer sense, $5^{\prime}$ CTG CGA CTC TCC CAC TGA 3'; NIS primer antisense, 5' CGC AGC TCT AGG TAC TGG TA 3'; NIS probe, 5' GCG AAC ACG CCG TAG TCC 3'; $\beta$-actin sense, $5^{\prime}$ GTG GGG CGC CCC AGG CACCA $3^{\prime}$; $\beta$-actin antisense, $5^{\prime}$ CTC CTT AAT GTC ACG CAC GAT TTC 3'; $\beta$-actin probe, $5^{\prime}$ CCG GAG TCC ATC ACG ATG CCA GTG GTA CGG 3'; 7B6 primer sense, 5' CGC AGG CTG AAG CGC AAG AG 3'; 7B6 primer antisense, 5' GGC CAC AAG AGA ACA GAA C 3'; GAPDH primer sense, 5' ATG GGG AAG GTG AAG GTC G 3'; GAPDH primer antisense, 5' GGG GTC ATT GAT GGC AAC A 3'.

Control reactions with RNA used as template were also carried out to exclude the possibility of genomic contamination and were consistently negative. In addition, DNA was extracted from FRTL-5 cells and subjected to 37 cycles of PCR amplification using the NIS primers. PCR products of $1200 \mathrm{bp}$ were amplified from genomic DNA, but the predicted $450 \mathrm{bp}$ product could not be detected, further excluding the possibility of PCR artefacts that may arise from genomic DNA contamination.

\section{Oligonucleotide hybridization}

Product identification was confirmed by hybridization using internal oligonucleotide probes, as described 

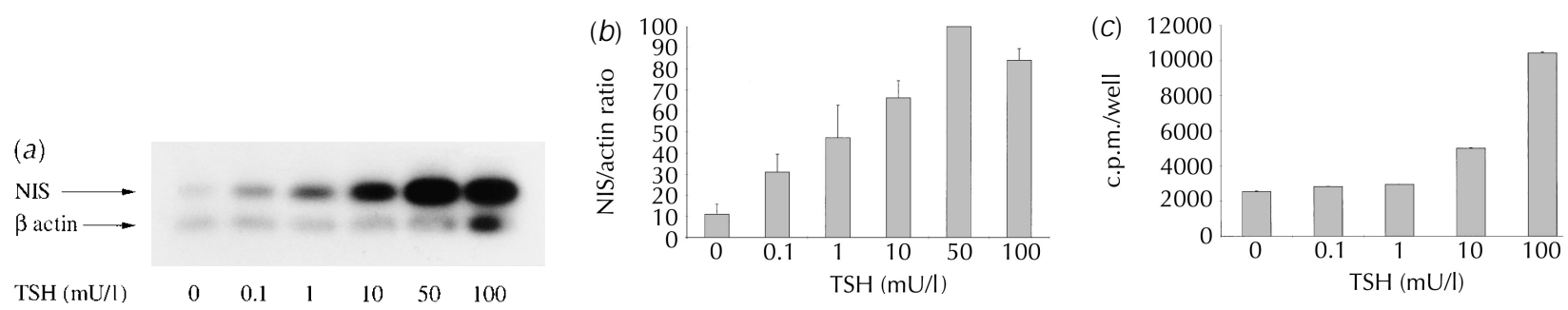

Figure 1 Effects of increasing concentrations of bovine TSH on NIS gene expression and iodide uptake in TSH-deprived FRTL-5 cells. (a) PCR amplification and Southern blot analysis of the NIS (upper lanes) and $\beta$-actin (lower lanes). Lane 0 , unstimulated cells; lanes $0 \cdot 1$, 1, 10, 50 and 100, cells stimulated with TSH (mU/l) for a period of $12 \mathrm{~h}$. (b) NIS/ $\beta$-actin ratio after determination of the intensity of the bands by densitometry. Results are presented as a percentage of the highest ratio. (c) lodide uptake in FRTL-5 cells presented as the mean counts/min per well (c.p.m. \pm S.E.M.) of duplicate cultures. Cells were unstimulated (0) or treated with 0·1, 1, 10 and $100 \mathrm{mU} / \mathrm{l}$ TSH for a period of $28 \mathrm{~h}$.

previously (Ajjan et al. 1996). In order to enhance the linearity of response of the radiographic film, preflashing was used throughout as described by Sambrook et al. (1989). The intensity of the bands was determined by densitometry, by the application of volume density analysis in the molecular analyst programme using the Biorad GS 690 scanning densitometer and the ratio of NIS/ $\beta$-actin was subsequently calculated.

\section{Iodide uptake}

FRTL-5 cells were cultured in 12-well plates and deprived of TSH, when they reached $70 \%$ confluence for a period of 5 days. Cells were then treated with increasing concentrations of either bTSH or hTSH with or without the addition of cytokines. After 24-28 h incubation, iodide uptake in these cells was determined by the addition of $8 \mathrm{kBq}$ of iodine-125 for a period of $1 \mathrm{~h}$. Cells were then washed quickly with ice-cold PBS, solubilised with $1 \mathrm{ml}$ $1 \mathrm{M}$ sodium hydroxide, and radioactivity was counted using a gamma counter. All experiments were performed in duplicate cultures.

\section{Results}

\section{NIS gene expression in FRTL-5 cells}

The expression of GAPDH, 7B6 and $\beta$-actin mRNA was compared in TSH-deprived and TSH-stimulated cells using triplex RT-PCR. Expression of these genes was similar in eight samples studied on three occasions (data not shown). Therefore, only one house-keeping gene $(\beta$-actin) was used in the remainder of the study.

Bovine TSH stimulated NIS gene expression in TSHdeprived FRTL-5 cells in a dose-dependent manner, reaching a peak at a concentration of $50 \mathrm{mU} / 1 \mathrm{bTSH}$ (Fig. 1). Human TSH had similar effects, but greater concentrations (10-10000 mU/l) were required (data not shown). The lower efficacy of hTSH is possibly due to altered glycosylation. TSH-induced NIS expression was evident after $6 \mathrm{~h}$ of TSH treatment, but not during the first $2 \mathrm{~h}$ (Fig. 2). TNFa inhibited TSH-stimulated NIS expression in a dose-dependent manner (Fig. 3), an effect that was detected with five different concentrations $(0 \cdot 1$, 1, 10, 50 and $100 \mathrm{mU} / \mathrm{l}$ ) of bTSH used (data not shown). The downregulation of TSH-stimulated NIS gene expression ranged from 65 to $75 \%$ when concentrations of $1000 \mathrm{U} / \mathrm{ml} \mathrm{TNF} \alpha$ were used (Fig. 4). TNF $\alpha$ also inhibited basal expression of NIS (Fig. 5). IL-1 $\alpha$ inhibited both basal and TSH-stimulated NIS expression, again in a dosedependent manner (Figs 3, 5), with an inhibition ranging from 65 to $80 \%$ when concentrations of $1000 \mathrm{U} / \mathrm{ml}$ IL-1 $\alpha$ were used (Fig. 4). IFN $\gamma$ also inhibited TSH-stimulated hNIS gene expression, but only at a concentration of $1000 \mathrm{U} / \mathrm{ml}$, with an inhibition ranging from 40 to $65 \%$ (Fig. 4), whereas it had no effects at concentrations of $100 \mathrm{U} / \mathrm{ml}$ or less (Fig. 3). Cell culture experiments were repeated on two occasions, and PCR amplifications were performed two or three times with each set of cell culture. The mean interassay coefficient of variation, determined by analysing 22 samples on three occasions, was $19 \%$ $( \pm 2 \cdot 7)$.

\section{Iodide uptake in FRTL-5 cells}

Iodide uptake in FRTL-5 cells increased after bTSH treatment in a dose-dependent manner, with an increase clearly evident with concentrations of $10 \mathrm{mU} / 1$ (Fig. 1c). Human TSH also increased iodide uptake in these cells, but again required greater concentrations to achieve effects similar to those of bTSH (data not shown). IL-1 $\alpha$, TNF $\alpha$ and IFN $\gamma$ all inhibited iodide uptake in these cells at concentrations of 100 and $1000 \mathrm{U} / \mathrm{ml}$, whereas little effect was detected with concentrations of $10 \mathrm{U} / \mathrm{ml}$ (Fig. 3).

\section{Tissue samples}

NIS expression was studied in Wistar rat thyroid, mammary gland, stomach, intestine, liver, fat, kidney and 
(a)

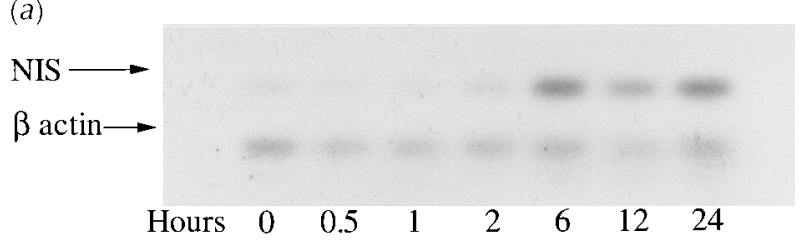

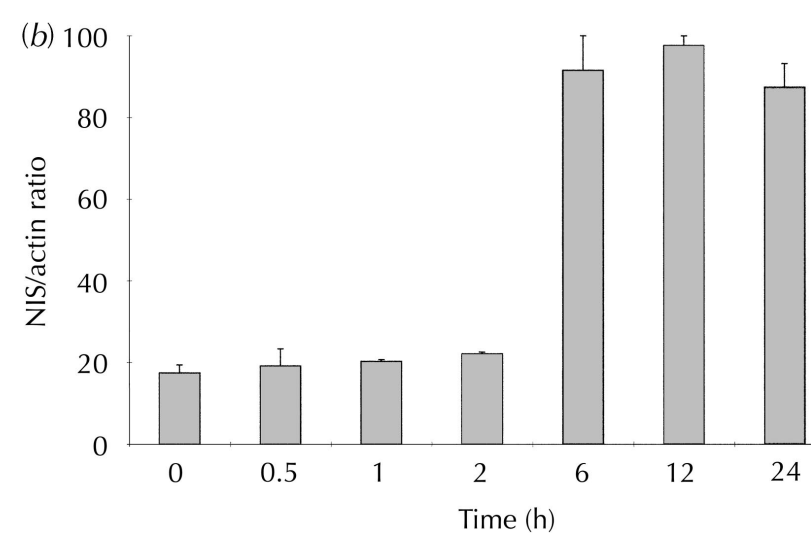

Figure 2 Time course of NIS gene expression in TSH-deprived FRTL-5 cells after TSH stimulation. (a) PCR amplification and Southern blot analysis of NIS (upper lanes) and $\beta$-actin (lower lanes). Lane 0, unstimulated cells; remaining lanes, cells treated with $100 \mathrm{mU} / \mathrm{ISH}$ for $0 \cdot 5$, $1,2,6,12$ and $24 \mathrm{~h}$. (b) NIS/ $\beta$-actin ratio after the determination of the intensity of the bands using densitometry. Results are presented as a percentage of the highest ratio.

salivary gland tissue samples (Fig. 6). Except for the kidney, NIS mRNA was detected in all tissue samples studied, but with varying levels of expression. The greatest level of expression was found in the thyroid and stomach, followed by the mammary gland. Lower levels were detected in the intestine and adipose tissue from the orbit, epididymis, shoulder and abdomen. Very low levels were detected in the liver, and borderline expression was found in the salivary gland. Using 37 cycles of PCR amplification, NIS expression was clearly detected in the salivary gland, but not in kidney tissues (data not shown).

\section{Discussion}

In the present study, we have developed a semiquantitative method, duplex RT-PCR, that overcomes

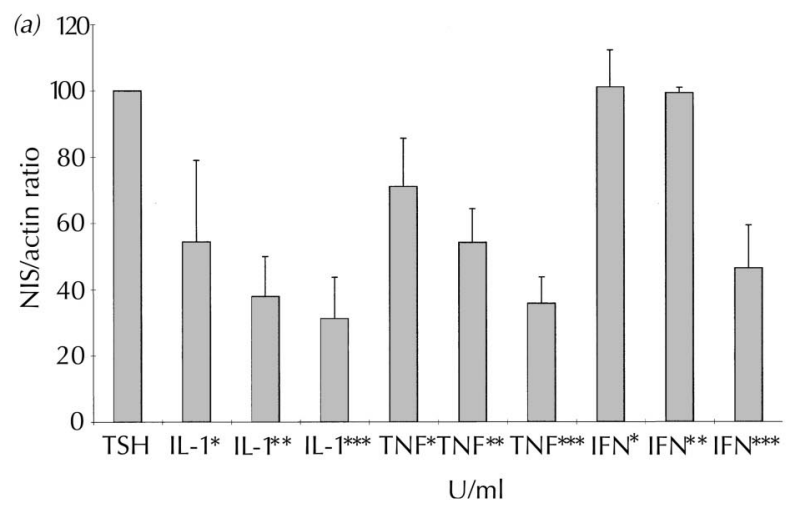

the limitations of qualitative PCR. This can be applied to analyse small numbers of cells or small tissue samples, which would not be possible using Northern blot or RNase protection assays. Duplex RT-PCR was used throughout this study, with primers both for NIS and for $\beta$-actin, a ubiquitously expressed housekeeping gene. This technique eliminates the artefacts that may arise from differences in first-strand cDNA synthesis between samples, and any variation in PCR conditions affects results obtained both with NIS and with $\beta$-actin. In addition, low numbers of cycles were used to demonstrate the abundance of the mRNA detected. A previous study has shown upregulation of $\beta$-actin gene expression after high-dose TSH treatment for an extended period of time (Phillips et al. 1989). In the present study, we included two additional house-keeping genes and showed that their expression was parallel to that of $\beta$-actin, ruling out

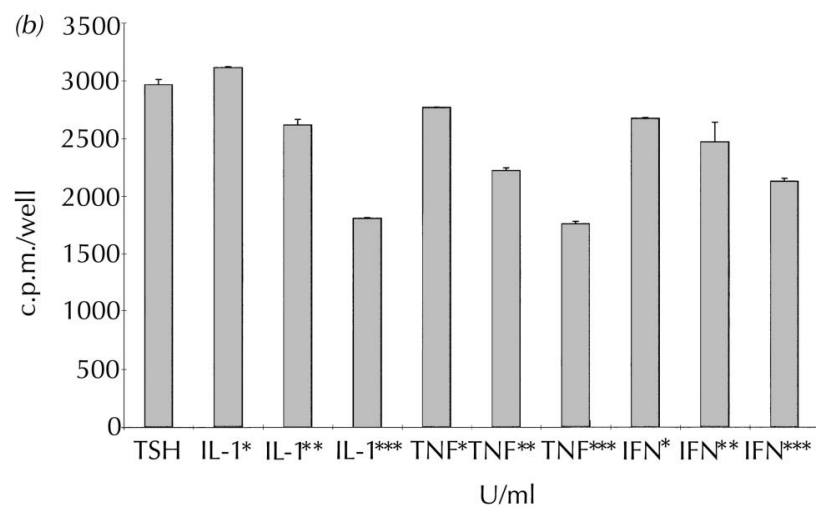

Figure 3 Effects of different concentrations of cytokines on TSH-stimulated NIS expression. Column 1, cells treated with $1 \mathrm{mU} / \mathrm{TSH}$ alone; columns 2-4, cells treated with TSH and IL-1 $\alpha$; columns 5-7, cells treated with TSH and TNF $\alpha$; columns 8-10, cells treated with TSH and IFN $\gamma$. Cytokine concentrations: ${ }^{*} 10 \mathrm{U} / \mathrm{ml} ;{ }^{* *} 100 \mathrm{U} / \mathrm{ml} ;{ }^{* * *} 1000 \mathrm{U} / \mathrm{ml}$. (a) Results of densitometric analysis of the Southern blots of the amplified PCR products, expressed as the mean ( \pm S.E.M.) ratio of NIS/ $\beta$-actin from two independent experiments. All results are expressed as a percentage of the highest ratio. All these cells were treated with TSH or TSH and cytokines for a period of $12 \mathrm{~h}$. (b) Results of iodide uptake, expressed as counts/min per well (c.p.m. \pm S.E.M.) of duplicate cultures. All these cells were treated with TSH or TSH and cytokines for a period of $24-28 \mathrm{~h}$. 

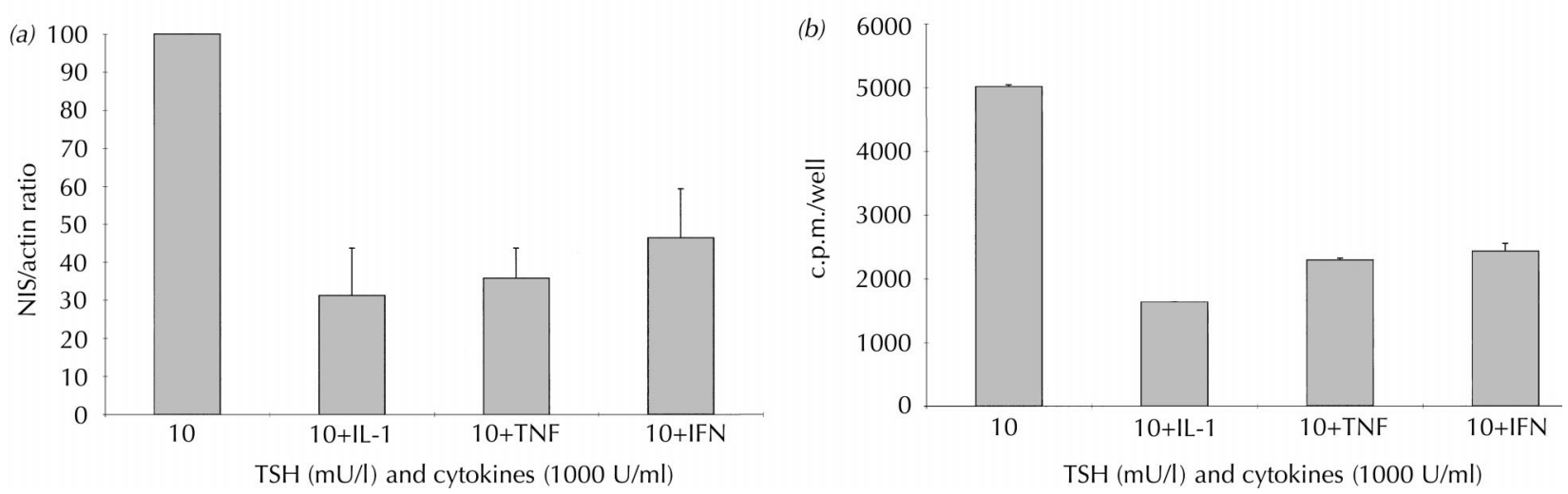

Figure 4 Effects of high concentrations of cytokines on NIS gene expression and iodide uptake. Column 1, cells treated with $10 \mathrm{mU} / \mathrm{l} \mathrm{TSH}$ alone; columns 2-4, cells treated with TSH and IL-1 $\alpha 1000 \mathrm{U} / \mathrm{ml}$, TNF $\alpha 1000 \mathrm{U} / \mathrm{ml}$, or IFN $\gamma 1000 \mathrm{U} / \mathrm{ml}$. (a) Results of densitometric analysis of the Southern blots of the amplified PCR products, expressed as the mean ( \pm S.E.M.) ratio of NIS/ $\beta$-actin from two independent experiments. All results are expressed as a percentage of the highest ratio. All these cells were treated with TSH or TSH and cytokines for a period of 12 h. (b) Results of iodide uptake, expressed as counts/min per well (c.p.m. \pm S.E.M.) of duplicate cultures. All these cells were treated with TSH or TSH and cytokines for a period of 24-28 h.

TSH-mediated regulation of $\beta$-actin mRNA expression in our cell line.

Previous studies on FRTL-5 cells have shown that iodide uptake is dependent on the presence of TSH in the culture medium. Iodide uptake in these cells is almost completely abolished after 1 week of TSH deprivation (Weiss et al. 1984a), and is restored by the readdition of TSH. In the present study, NIS gene expression was constitutively expressed in TSH-deprived FRTL-5 cells, and was upregulated after TSH treatment, an effect detected after $6 \mathrm{~h}$ of stimulation, but not during the first $2 \mathrm{~h}$. A recent study using Northern blot analysis has also shown similar effects of TSH regulation of NIS mRNA

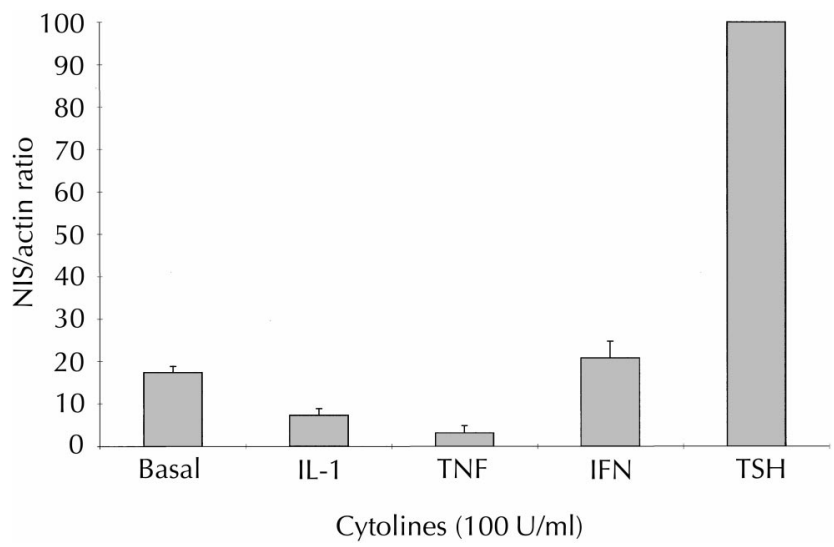

Figure 5 Effects of cytokines on the basal expression of NIS in TSH-deprived FRTL-5 cells. Results are expressed as the ratio of $\mathrm{NIS} / \beta$-actin, after densitometric analysis of the Southern blots of the amplified PCR products. Column 1, untreated (basal) cells; columns 2-5, cells treated with IL-1 $\alpha$, TNF $\alpha$, IFN $\gamma$ and TSH $(100 \mathrm{U} / \mathrm{ml}$ each) respectively. Results are expressed as a percentage of the highest ratio (TSH-treated cells). expression in FRTL-5 cells and demonstrated dependence on adenylate cyclase activation (Kogai et al. 1997). The readdition of TSH to TSH-deprived FRTL- 5 cells results in increased iodide uptake after a latency period of 12-24 h, taking $60 \mathrm{~h}$ before cells reach full iodide uptake capacity (Weiss et al. 1984a). Therefore, it seems likely that this response is due, at least in part, to the induction of NIS gene expression, which is enhanced within $6 \mathrm{~h}$ of TSH treatment, taking a further 12-24 h for the appearance of biological activity. Although NIS mRNA levels were increased after bTSH stimulation from concentrations as low as $0.1 \mathrm{mU} / 1$, no significant increase in iodide uptake was detected at concentrations less than $10 \mathrm{mU} / 1$ at $24-28 \mathrm{~h}$. This is probably due to the time

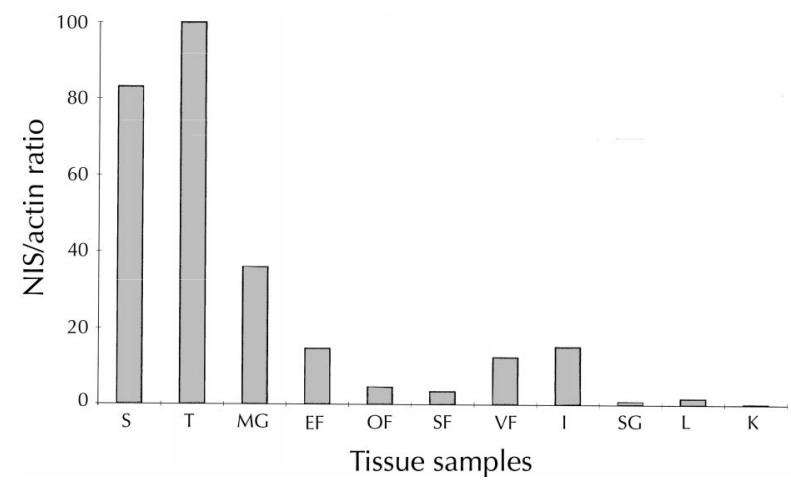

Figure 6 Tissue distribution of NIS mRNA in Wistar rats. Results are expressed as the ratio of NIS/ $\beta$-actin after densitometric analysis of the Southern blots of the amplified PCR products. $\mathrm{S}$, stomach tissue; $\mathrm{T}$, thyroid tissue; $\mathrm{MG}$, lactating mammary gland tissue; EF, OF, SF, VF, epididymal, orbital, shoulder and visceral adipose tissues; I, intestinal tissue; SG, salivary gland tissue; L, liver tissue; K, kidney tissue. Results are expressed as a percentage of the highest ratio (thyroid tissue). 
required for protein synthesis, as optimal iodide uptake in FRTL-5 cells is usually detected after $60 \mathrm{~h}$ of TSH stimulation (Weiss et al. 1984a).

The importance of NIS expression in iodide uptake was further emphasised in a recent study which showed that NIS mRNA is not expressed in thyroid carcinoma cell lines that have lost iodide uptake activity (Smanik et al. 1996). In contrast, the constitutive expression of NIS gene in TSH-deprived FRTL-5 cells may explain the findings of Kaminsky et al. (1994), who have demonstrated that membrane vesicles prepared from FRTL-5 cells maintained in TSH-free medium are able to accumulate iodide. It was proposed that NIS protein is present in TSHdeprived FRTL-5 in an inactive form, and is activated upon the readdition of TSH, through unknown mechanisms. Therefore, it is possible that downregulation of the NIS gene in FRTL-5, in the absence of TSH, is only partly responsible for the decreased iodide uptake, and the symporter is present in these cells, but inactive because of the absence (or presence) of other unknown modulating factors regulated by TSH.

The role of cytokines in regulating thyroid function has been the focus of many studies over the past few years. It has been shown previously that TNF $\alpha$ inhibits FRTL-5 iodide uptake in vitro (Pang et al. 1993), whereas prolonged administration of TNFa to mice produced a dosedependent decrease in concentrations of tri-iodothyronine $\left(\mathrm{T}_{3}\right)$, thyroxine and recombinant $\mathrm{T}_{3}$ (Ozawa et al. 1988). Administration of TNF $\alpha$ to healthy volunteers induces changes in TSH and thyroid hormones resembling those found in non-thyroidal illness (NTI), suggesting involvement of TNF $\alpha$ in NTI, in patients with infections or malignancy, in whom production of TNF is a feature (Van der Poll et al. 1990). In our study, TNFa inhibited both constitutive and TSH-stimulated NIS gene expression in vitro, indicating that the above effects of TNFa may be due, at least in part, to inhibition of NIS gene transcription. TNF $\alpha$ produced by the lymphocytic infiltrate in autoimmune thyroid disease may inhibit NIS mRNA expression. Hashimoto's thyroiditis-derived lymphocytes produce TNFa (Del Prete et al. 1989), and thus it is possible that suppression of NIS gene expression by TNFa plays a part in hypothyroidism in the early stages of Hashimoto's thyroiditis, before widespread tissue destruction becomes evident later in the disease process. A similar mechanism may partially counter the effect of thyroid stimulating antibodies (TSAb) in Graves' disease, in which intrathyroidal TNF $\alpha$ also occurs (Zheng et al. 1992, Aust et al. 1996). This would contribute to the lack of correlation between the level of TSAb and the severity of clinical hyperthyroidism (Takata et al. 1980).

The effects of IL- $1 \alpha$ on NIS gene expression mimicked those of TNF $\alpha$, whereas IFN $\gamma$ had an effect only when high concentrations of this cytokine were used. A good correlation between NIS gene expression and iodide uptake in FRTL-5 cells was detected, suggesting that cytokines affect iodide uptake in these cells by directly modulating NIS mRNA expression. Clinical considerations similar to those for TNF $\alpha$ would apply to the action of IL- $1 \alpha$ and IFN $\gamma$ on the NIS.

We have studied the tissue distribution of NIS and shown that iodide transporting tissues, including the stomach, mammary gland and thyroid, express high levels of the symporter. The intestine in rats also concentrates iodide, an activity that is maximal in the middle region of the small intestine (Pastan 1957). We have detected relatively low levels of NIS mRNA in the intestine, which is possibly due to the analysis of tissues containing both iodide transporting and non-transporting intestinal segments. Northern blotting has failed to detect NIS mRNA in rat intestine (Dai et al. 1996), emphasising the greater sensitivity of RT-PCR used in the current study.

The salivary glands typically transport iodide in many species; however, this is not the case in rats (Brown-Grant 1961, Wolff 1964). In the present study, only borderline levels of NIS mRNA were detected in the salivary glands. This probably explains earlier reports that have studied different rat species and shown that rat salivary glands are unable to concentrate iodide (Brown-Grant 1961, Wolff 1964).

An unexpected finding was the expression of NIS in organs that are believed not to transport iodide. Rat liver, which has been shown to lack NIS mRNA using Northern blotting (Dai et al. 1996), expressed the symporter. These contradictory results are probably due to the greater sensitivity of the PCR method we used, although only 27 cycles of PCR amplification were applied. NIS was also detected in adipose tissue excised from different sites, namely the epididymis, shoulder, abdomen and, most importantly, the orbit. It has been suggested recently that NIS is a novel autoantigen, as antibodies in a serum sample from a patient with Hashimoto's thyroiditis inhibited iodide uptake in dog thyrocyte cultures (Raspé et al. 1995). In addition, recombinant rat NIS reacted with $84 \%$ of sera from patients with Graves' disease (Endo et al. 1996b). More recently, four of 34 sera from patients with Hashimoto's thyroiditis were shown to inhibit iodide uptake in Chinese hamster ovary cells stably expressing the rat NIS (Endo et al. 1996a). Furthermore, these sera reacted with a synthetic peptide corresponding to the sixth extracellular loop of NIS. The detection of NIS mRNA in orbital fat, together with the above findings, suggests that NIS is a candidate autoantigen involved in thyroid-associated ophthalmopathy, particularly in view of the greater incidence of the autoantibodies to the NIS in Graves' disease compared with Hashimoto's thyroiditis. However, NIS expression remains to be demonstrated in human retro-ocular tissue, and mRNA expression does not necessarily correlate with protein production. In addition, illegitimate transcription can sometimes produce artefactual signals (Chelly et al. 
1989). We performed 33 cycles to amplify NIS from the orbit, but this was because of poor yield of mRNA secondary to scarcity of the tissue, supported by the need to apply 29 cycles (compared with 23 in other samples) in order to detect $\beta$-actin-specific PCR product. The possibility of genomic contamination is ruled out by the inability to amplify any NIS product when PCR was carried out on RNA before reverse transcription. Furthermore, when genomic DNA from FRTL-5 cells was amplified using the NIS primers, we obtained a product of $1200 \mathrm{bp}$, suggesting that our primers span intron-exon boundaries, although the structure of the NIS gene has yet to be reported.

In summary, NIS gene expression in FRTL-5 cells is regulated by TSH and can be modulated by cytokines. The analysis of NIS gene tissue distribution in rats has shown that known iodide transporting tissues generally express high levels of NIS mRNA, and that this can also be detected, albeit at lower levels, in tissues that are believed not to transport iodide.

\section{Acknowledgements}

This work was funded by a grant from the Northern General Hospital, Sheffield. R A Ajjan is funded by grants from the Overseas Research Award and the University of Sheffield. We are grateful to Dr L Kohn for the provision of FRTL-5 cells.

\section{References}

Ajjan RA, Watson PF, McIntosh RS \& Weetman AP 1996 Intrathyroidal cytokine gene expression in Hashimoto's thyroiditis. Clinical and Experimental Immunology 105 523-528.

Aust G, Heuer M, Leue S, Lehmann I, Hofmann A, Heldin NE \& Scherbaum WA 1996 Expression of tumour necrosis factor-alpha mRNA and protein in pathological thyroid tissue and carcinoma cell lines. Clinical and Experimental Immunology 105 148-154.

Bagnasco M, Ferini S, Venuti D, Prigione I, Torre G, Biassoni R \& Canonica GW 1987 Clonal analysis of T lymphocytes infiltrating the thyroid gland in Hashimoto's thyroiditis. International Archive of Allergy and Applied Immunology 82 141-146.

Brown-Grant K 1961 Extrathyroidal iodide concentrating mechanisms. Physiological Reviews 41 189-213.

Carrasco N 1993 Iodide transport in the thyroid gland. Biochimica et Biophysica Acta 1154 65-82.

Chambard M, Verrier B, Gabrion J \& Mauchamp J 1983 Polarization of thyroid cell culture: evidence for the basolateral localization of the iodide pump and of the thyroid-stimulating hormone receptor-adenyl cyclase complex. Journal of Cell Biology 96 $1172-1177$.

Chelly J, Concordet JP, Kaplan JC \& Kahn A 1989 Illegitimate transcription: transcription of any gene in any cell type. Proceedings of the National Academy of Sciences of the USA 86 2617-2621.

Dai G, Levy O \& Carrasco N 1996 Cloning and characterization of the thyroid iodide transporter. Nature 379 458-460.

Del Prete GF, Tiri A, De Carli M, Meriotti S, Pinchere A, Chretien I, Romegnani S \& Ricci M 1989 High potential to tumour necrosis factor- $\alpha$ production of thyroid infiltrating lymphocytes in Hashimoto's thyroiditis: a peculiar feature of thyroid autoimmunity. Autoimmunity 4 267-276.

Endo T, Kaneshige M, Nakazato M, Kogai T, Saito T \& Onaya T 1996a Autoantibodies against thyroid iodide transporter in the sera of patients with Hashimoto's thyroiditis possesses iodide transport inhibitory activity. Biochemical and Biophysical Research Communications 228 199-202.

Endo T, Kogai T, Nakazato M, Saito T, Kaneshige M \& Onaya T $1996 b$ Autoantibody against $\mathrm{Na}^{+} / \mathrm{I}^{-}$symporter in the sera of patients with autoimmune thyroid disease. Biochemical and Biophysical Research Communications 224 92-95.

Halmi NS 1961 Thyroidal iodide transport. Vitamins and Hormones 19 $133-163$

Huber GK \& Davies TF 1990 Human fetal thyroid cell growth in vitro: system characterization and cytokine inhibition. Endocrinology 126 869-875.

Kaminsky SM, Levy O, Salvador C, Dai G \& Carrasco N 1994 $\mathrm{Na}^{+} / \mathrm{I}^{-}$symport activity is present in membrane vesicles from thyrotropin-deprived non $\mathrm{I}^{-}$transporting cultured thyroid cells. Proceedings of the National Academy of Sciences of the USA 91 3789-3793.

Kogai T, Endo T, Saito T, Miyazaki A, Kawaguchi A \& Onaya T 1997 Regulation by thyroid-stimulating hormone of sodium/iodide symporter gene expression and protein levels in FRTL-5 cells. Endocrinology 138 2227-2232.

Ozawa M, Sato K, Han DC, Kawakami M, Tsushima T \& Shizume K 1988 Effects of tumor necrosis factor-alpha/cachectin on thyroid hormone metabolism in mice. Endocrinology $\mathbf{1 2 3}$ 1461-1467.

Pang XP, Yoshimure M \& Hershmen JM 1993 Suppression of rat thyrotroph and thyroid cell function by tumour necrosis factor $\alpha$. Thyroid 3 325-330.

Pastan I 1957 Absorption and secretion of iodide by the intestine of the rat. Endocrinology 61 93-97.

Phillips ID, Black EG, Sheppard MC \& Docherty K 1989 Thyrotropin, forskolin and ionomycin increase cathepsin B mRNA concentrations in rat thyroid cells in culture. Journal of Molecular Endocrinology 2 207-212.

Rasmussen AK, Kayser L, Rasmussen UF \& Bendtzen K 1994 Influence of tumour necrosis factor- $\beta$ and interferon $-\gamma$, separately and added together with interleukin- $1 \beta$, on the function of cultured human thyroid cells. Journal of Endocrinology 143 359365.

Raspé E, Costagliola S, Ruf J, Mariotti S, Dumont JE \& Ludgate M 1995 Identification of the thyroid $\mathrm{Na}^{+} / \mathrm{I}^{-}$cotransporter as a potential autoantigen in thyroid autoimmune disease. European Journal of Endocrinology 132 399-405.

Sambrook J, Fritch EF \& Maniatis T 1989 Autoradiography. In Molecular Cloning: A Laboratory Manual, vol 3, E21-E23. Cold Spring Harbor: Cold Spring Harbor Laboratory Press.

Smanik PA, Liu Q, Furminger TL, Ryu K, Xing S, Mezzoferri EL \& Jhiong SM 1996 Cloning of the human sodium iodide symporter. Biochemical and Biophysical Research Communications 226 339-345.

Takata I, Suzuki Y, Saida K \& Sato T 1980 Human thyroid stimulating activity and thyroid state in antithyroid treatment of juvenile Graves' disease. Acta Endocrinologica 94 46-52.

Tandon N, Makgoba MW, Gahmberg CG \& Weetman AP 1992 The expression and role in T cell adhesion of LFA-3 and ICAM-2 on human thyroid cells. Clinical Immunology and Immunopathology 64 $30-35$.

Todd I, Pujol-Borrell R, Hammond LJ, Bottazzo GF \& Feldmann M 1985 Interferon- $\gamma$ induces HLA-DR expression by thyroid epithelium. Clinical and Experimental Immunology 11 265-273.

Tominaga T, Yamashita S, Nagayama Y, Morite S, Yokoyama N, Igumi M \& Negetaki S 1991 Interleukin-6 inhibits human thyroid peroxidase gene expression. Acta Endocrinologica 124 290-296. 
Van der Poll T, Romijn JA, Wiersinga WM \& Sauerwein HP 1990 Tumor necrosis factor: a putative mediator of the sick euthyroid syndrome in man. Journal of Clinical Endocrinology and Metabolism 71 $1567-1572$.

Vargas F, Tolosa E, Sospedra M, Cataffarno M, Lucas-Maxtin A, Obiols G et al. 1994 Characterization of neural cell adhesion molecule (NCAM) expression in thyroid follicular cells: induction by cytokines and over-expression in autoimmune glands. Clinical and Experimental Immunology 98 478-488.

Watson PF, Pickerill AP, Davies R \& Weetman AP 1995 Semi-quantitative analysis of interleukin-1 $\alpha$, interleukin-6 and interleukin-8 mRNA expression by human thyrocytes. Journal of Molecular Endocrinology 15 11-21.

Weetman AP \& Rees AJ 1988 Synergistic effects of recombinant tumour necrosis factor- $\alpha$ (TNF) and $\gamma$-interferon $(\gamma$-IFN) on rat thyroidal cell growth and Ia antigen expression. Immunology 63 285-289.
Weiss SJ, Philp NJ, Ambesi-Impiombato FS \& Grollman EF 1984a Thyrotropin-stimulated iodide transport mediated by adenosine $3^{\prime}, 5^{\prime}$-monophosphate and dependent on protein-synthesis. Endocrinology 114 1099-1107.

Weiss SJ, Philp NJ \& Grollman EF $1984 b$ Iodide transport in a continuous line of cultured-cells from rat-thyroid. Endocrinology 114 1090-1098.

Wolff J 1964 Transport of iodide and other anions in the thyroid gland. Physiological Reviews 44 45-90.

Zheng RQH, Abney ER, Chu CQ, Field M, Maini RN, Lamb JR \& Feldmann M 1992 Detection of in vivo production of tumour necrosis factor-alpha by human thyroid epithelial cells. Immunology $75456-462$.

Received 19 August 1997

Revised manuscript received 19 January 1998 Accepted 29 April 1998- 